Szymon Bauman

(Poznań)

mgr, szybau@gmail.com

ORCID iD: 0000-0002-2580-4385

\title{
Nieznany wyrób pieczętarski Fryderyka Wilhelma Belowa (Komunikat)
}

W zbiorach prywatnych autora znajduje się niedawno nabyty na aukcji internetowej, dotąd nieznany stempel pieczętny ${ }^{1}$, który wykonał poznański pieczętarz i medalier Fryderyk Wilhelm Below (1822-1895)². Wysokość całko-

\footnotetext{
${ }^{1}$ Rozróżnienie tłoka i stempla pieczętnego polega na rozpoznaniu sposobu rytu matrycy (wklęsły lub wypukły), to zaś związane jest z ich przeznaczeniem (do laku lub tuszu). Ostatnio Władysław Fabijański wyjaśnił te dwa terminy w następujący sposób: „[...] pod nazwą «łłok pieczętny» należy rozumieć tę pieczęć (najczęściej wykonaną w metalu), której matryca jest wklęsła, z wizerunkiem w negatywie, i stosowana do sporządzenia z niej odcisku głównie w masie plastycznej typu: wosk, lak, papier z podkładem woskowym, papier suchy, ołów, plastelina [...]. Natomiast pod nazwą «stempel pieczętny» należy rozumieć taką pieczęć (najczęściej wykonaną w metalu, ale także w drewnie lub kauczuku), której matryca jest wypukła, z wizerunkiem w negatywie, a która służy do sporządzenia odcisku tuszem bezpośrednio na papierze dokumentu", W. Fabijański, Próba klasyfikacji i nazewnictwa pieczęci używanych w kancelariach urzędów oraz instytucji polskich XX wieku, [w:] Dawne pieczęcie: typologia - metody badań - interpretacje, pod red. Z. Piecha, Warszawa 2015, s. 554, przypis 1. Michał Gradowski dokonał podobnego rozróżnienia tłoka i stempla: „pieczęć sucha, przeznaczona do robienia odcisków w wosku, laku itp., ma wyobrażenia wygrawerowane wgłębnie (intaglio), a opracowane na wszystkich poziomach głębokości łącznie z tłem, natomiast pieczęć mokra, przeznaczona do odcisków tuszem, posiada wybrane wgłębnie i nie opracowane plastycznie tło, działa bowiem tylko powierzchnią czołową", M. Gradowski, Dawne złotnictwo: technika i terminologia, Warszawa 1984, s. 145.

${ }^{2} \mathrm{Na}$ temat F.W. Belowa napisano stosunkowo wiele przyczynków i nieco szerszych opracowań: E. Majkowski, Fryderyk Wilhelm Below: pieczętarz i medaljer poznański, patriota polski (18221895), „Kronika Miasta Poznania” [dalej: KMP] 1936, r. 14, nr 3, s. 263-349 (zob. też krótką recenzję Adama Soleckiego, „Wiadomości Numizmatyczno-Archeologiczne” 1936, t. 28, s. 138-139); tegoż, Fryderyk Wilhelm Below, [w:] Polski stownik biograficzny, t. I, s. 407-408; tegoż, Nieznana praca medalierska Fryderyka Wilhelma Belowa, rytownika i pieczętarza poznańskiego, „Kronika Stołecznego Miasta Poznania" 1946, r. 19, nr 1, s. 58-62; L. Formanowicz, Przyczynek do działalności rytowniczej Fryderyka Wilhelma Belowa, KMP 1936, r. 14, nr 3, s. 490-494; P. Michałowski, Below Fryderyk
} 


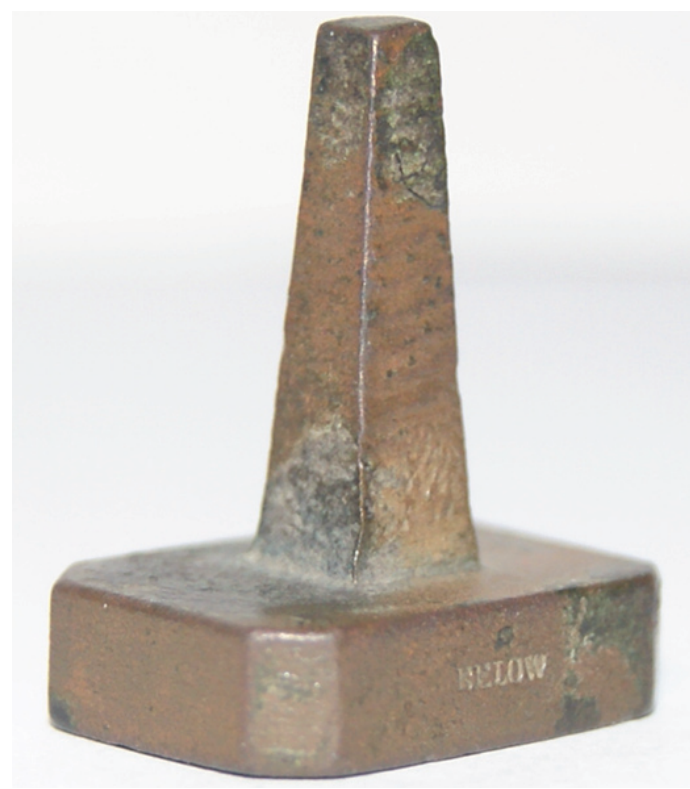

Fot. 1. Stempel pieczętny wykonany przez Fryderyka Wilhelma Belowa

wita obiektu (wraz z trzpieniem) wynosi $23 \mathrm{~mm}$, a wymiary samego stempla wynoszą $19 \mathrm{~mm}$ x $14 \mathrm{~mm}$ (długość i szerokość) i jego wysokość $5 \mathrm{~mm}$ (fot. 1). Niniejszy artefakt jest prawie miniaturowy - aby móc to dodatkowo zobrazować, podajemy wymiary sygnatury $B E L O W$, umieszczonej na rancie stempla: $4 \mathrm{~mm} \times 1 \mathrm{~mm}$ (fot. 2$)^{3}$.

Wilhelm (1822-1895), [w:] Wielkopolski stownik biograficzny, Warszawa-Poznań 1981, s. 46; Z. Grot, F.W. Below: wybitny medalier wielkopolski i patriota, "Złotnik i Zegarmistrz" 1936, nr 8, s. 154-155; J. Derwojed, Below Fryderyk Wilhelm, [w:] Stownik artystów polskich i obcych w Polsce działających: malarze, rzeźbiarze, graficy, red. J. Maurin-Białostocka, M. Biernacka i in., Wrocław-WarszawaKraków-Gdańsk 1971, t. 1, s. 124-25; J. Strzałkowski, Stownik medalierów polskich i z Polską zwiazanych 1508-1965 (materiaty), Warszawa 1982, s. 26; A. Brosig, Dzieje sztuki litograficznej w Poznaniu, KMP 1936, r. 14, nr 4, s. 435; Spis złotników poznańskich w XIX wieku - do pocz. XX w., oprac. Z. Dolczewski, KMP 2000, nr 1, s. 144; M. Gumowski, Medale polskie, Warszawa 1925, s. 153-154 (pomylił Fryderyka z jego synem Stefanem); S. Gibasiewicz, Medalierzy poznańscy XIX wieku, [w:] Materiały z I Ogólnopolskiej Sesji Medalierskiej, red. J. Hrybacz, Z. Nowakowska, T. Szczurek, Gorzów Wielkopolski 1974, s. 29-32; A. Więcek, Dzieje sztuki medalierskiej w Polsce, Kraków 1989, s. 154-155; J.I. Sztakelberg, Pieczęcie powstańcze 1863-1864, przedmowa S. Kieniewicz, tabl. i il. do druku przygotował S.K. Kuczyński, przekł. W. Śliwowska, Warszawa 1988, s. 74-75; P. Stróżyk, Pieczęć naczelnika miasta Poznania z okresu powstania styczniowego. Zagadnienia autorstwa, [w:] Pomerania et alia. Opuscula Joachimo Zdrenka dedicata, red. J. Karczewska, M. Tureczek, Toruń 2017, s. 275-280. Zob. także AP Poznań, Akta miasta Poznania - Kartoteka ewidencji ludności 1870-1931, sygn. 14270, k. 551-552 (karta meldunkowa).

${ }^{3}$ Głównym argumentem przemawiającym za F.W. Belowem jako wytwórcą publikowanego stempla oraz datowaniem obiektu na pierwszą ćwierć drugiej połowy XIX w., jest fragment 


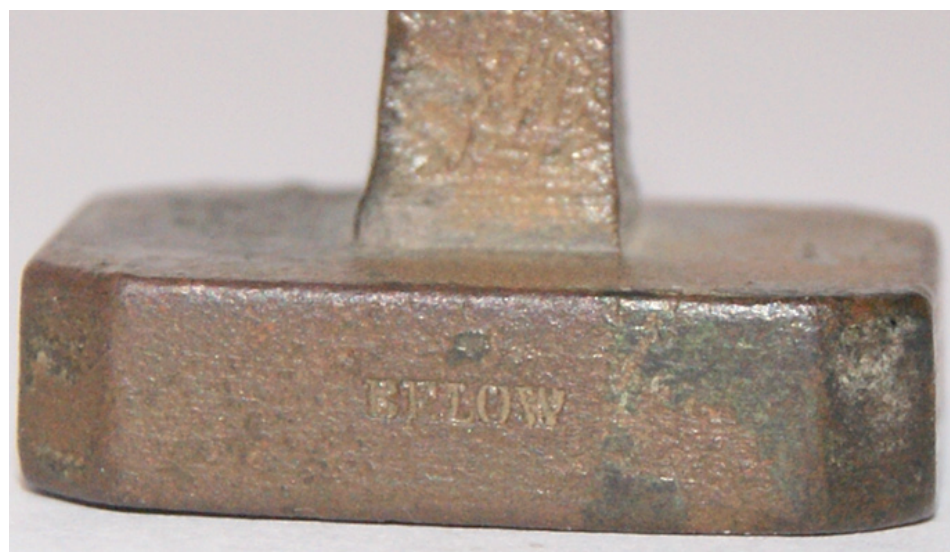

Fot. 2. Sygnatura wytwórcy na rancie stempla, która poza funkcją informacyjną odgrywała także rolę znacznika jego prawidłowego ustawienia

Stempel posiada napis składający się z trzech liter majuskulnych N. S. G., które wyryto wypukle w negatywie. Napis ten tworzą inicjały właściciela pieczęci (fot. 3) ${ }^{4}$. Osoba fizyczna lub prawna kryjąca się pod wymienionymi literami zapewne zleciła również jego wykonanie. Umieszczony w polu pieczęci napis, w jednym wierszu, otacza delikatna perełkowa obwódka i tuż za nią zewnętrznie linia ciągła. Stempel ma charakterystyczny kształt czworokątny ze ściętymi w skos narożnikami. W swojej ogólnej kompozycji niniejsza pieczęć nie odbiega od wielu dziewiętnastowiecznych pieczęci osób prywatnych ${ }^{5}$. Trudniej powiedzieć, z jakiego materiału ją wykonano. Najogólniej można stwierdzić, że jest to metal - dokładniej: być może brąz bądź mosiądz. Precyzyjne określenie materiału, w którym zostały wykonane tego typu artefakty, należałoby oprzeć na specjalistycznej analizie materiałoznawczej, lecz „W wielu przypadkach archiwista dysponuje zbyt ograniczoną wiedzą, by ustalić surowiec użyty do sporządzenia tłoka" ${ }^{\prime \prime}$. Publikowany obiekt jest nie-

artykułu Edmunda Majkowskiego mówiący o tym, że „Below sygnował swe prace pieczętarskie zazwyczaj małym stempelkiem, który odbijał na rancie tłoka pieczętnego. Pierwotnie był to stempelek jednowierszowy: BELOW, później dwuwierszowy: W. BELOW - POSEN", cyt. za: E. Majkowski, Fryderyk Wilhelm Below: pieczętarz..., s. 300.

${ }^{4}$ Autorowi nie udało się, mimo usilnych starań, odszukać właściciela tej pieczęci.

${ }^{5}$ Por. m.in.: J. Trupinda, Tłoki pieczętne w zbiorach Muzeum Narodowego w Gdańsku, „Rocznik Gdański" 2000, t. 60, z. 2, s. 107, fot. nr 7; G. Sukiennik, Katalog tłoków pieczętnych w zbiorach Biblioteki Ossolineum. Nabytki z lat 1978-1984, "Ze Skarbca Kultury” 1987, z. 44, s. 250, poz. 110; K. Kłudkiewicz, Księgozbiór kolekcjonera dzieł sztuki. Słów kilka o bibliotece Seweryna hr. Mielżyńskiego z Miłosławia, "Biblioteka” 2015, nr 19, s. 91-92; Pamiątki przeszłości 1796-1945: berlińska linia Radziwiłtów. Muzeum w Nieborowie i Arkadii i Fundacja Trzy Traby, 16 czerwca - 31 października 2018, Nieborów 2018, nr kat. 57.

${ }^{6}$ Cyt. za: P. Gut, Problemy inwentaryzacji kolekcji tłoków pieczętnych w Archiwum Państwowym w Szczecinie, „Archiwista Polski” [dalej: Arch. Pol.] 2007, nr 1, s. 12. 


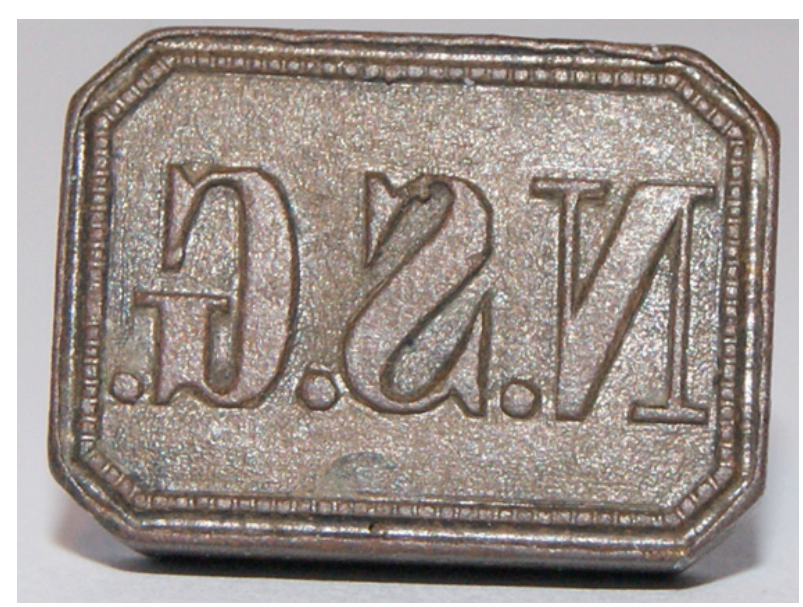

Fot. 3. Matryca z rytymi wypukle inicjałami N. S. G.

łatwo wydatować, przede wszystkim dlatego, że nie udało się odnaleźć dysponenta pieczęci, toteż przydatnym okaże się zarysowanie działalności jego wytwórcy.

Below działał w Poznaniu przez niemal całą drugą połowę XIX w. Jeszcze $\mathrm{w}$ latach szkolnych, które przypadały na lata 30. XIX w., podjął praktykę rzemieślniczą u jednego z poznańskich grawerów ${ }^{7}$. Po zakończeniu edukacji, w 1841 lub 1842 r., udał się do stolicy Prus, gdzie kontynuował naukę zawodu. Pobyt w Berlinie nie trwał jednak długo, ponieważ pojawiła się możliwość założenia własnego warsztatu w Poznaniu ${ }^{8}$. Nie znamy dokładnej daty powrotu Belowa, zatem można tylko domniemywać, kiedy założył swój zakład. Edmund Majkowski przypuszcza, że nastąpiło to w latach 1843-18449. Następnie, samodzielnie pracującemu od zaledwie kilku lat rzemieślnikowi, trafiło się nader intratne zlecenie, które było związane z reformą pieczęci kościelnych $\mathrm{w}$ archidiecezji gnieźnieńskiej i poznańskiej, zainicjowaną przez abp. Leona Przyłuskiego w latach 1846-1852 ${ }^{10}$. Below został bowiem wskazany jako jeden z dwóch wykonawców nowych pieczęci dla Kościoła, wraz z drugim pieczętarzem - Feliksem Dmochowskim ${ }^{11}$. Jak napisał autor dotąd najszerszej pracy na temat życia artystycznego Belowa: „Z czasem stał się Below wyłącznym dostawcą pieczęci kościelnych, które rytował tak dla naj-

\footnotetext{
${ }^{7}$ E. Majkowski, Fryderyk Wilhelm Below: pieczętarz..., s. 270.

8 Tamże, s. 271-273.

${ }^{9}$ Tamże, s. 273.

10 Tamże, s. 273-274 i 291-297.

${ }^{11}$ Szerzej o Feliksie Dmochowskim w artykule zamieszczonym w niniejszym tomie, zob. S. Bauman, P. Chrząszcz, Wytwórcy i sprzedawcy pieczęci ogłaszajacy się w prasie poznańskiej w latach 1815-1939, „Przegląd Archiwalno-Historyczny” 2019, t. 6, s. 141-143.
} 
wyższych duchownych, jak dla urzędów parafialnych i dla księży samych. Z tych ostatnich posiadał wtedy każdy, według panującego zwyczaju, własną pieczątkę do laku, zrobioną częstokroć bardzo ozdobnie i artystycznie. Nie brakowało więc Belowowi pracy; to zaś, co z jego [pieczęci - S.B.] kościelnych zebrałem, stanowi bodaj cząstkę jego całkowitego dzieła pieczętarskiego. Władze zaborcze pruskie i niemieckie urzędy świeckie rzadko tylko korzystały, mimo tytułu nadwornego grawera sasko-meiningskiego [patent otrzymał w 1846 r. - S.B.], z jego biegłości w rytowaniu pieczęci"12.

Kolejne lata upłynęły Fryderykowi na codziennej pracy zawodowej, wśród której rytownictwo pieczęci było wciąż dominujące ${ }^{13}$. Jako znakomity wyrzynacz pieczęci, ale przede wszystkim jako polski patriota, włączył się w działania konspiracyjne na rzecz powstania styczniowego. Below zaczął wykonywać pieczęcie dla władz powstańczych, za co został aresztowany 22 lipca 1864 r., lecz szybko go uniewinniono i wypuszczono, przez co mógł powrócić do spokojnej i pracowitej egzystencji ${ }^{14}$. Fryderyk pracował niemal do końca swego życia. Zmarł nagle, w piątek wieczorem 19 lipca 1895 r., podczas czytania gazety ${ }^{15}$.

Działalność artystyczno-pieczętarską Belowa datujemy więc na drugą połowę XIX w., ściślej od założenia warsztatu w Poznaniu w 1843 lub 1844 r., do śmierci artysty w $1895 \mathrm{r}$. (w tym czasie najpewniej wykonał niżej publikowaną pieczęć). Niemniej jednak nie można pominąć faktu, iż zakłady Fryderyka istniały dalej, albowiem pracownię artystyczno-grawerską, znajdującą się przy ul. Wrocławskiej, przejął po śmierci Belowa jego syn - Stefan Jakub (zm.

${ }^{12}$ Cyt. za: E. Majkowski, Fryderyk Wilhelm Below: pieczętarz..., s. 274.

${ }^{13} \mathrm{~W}$ wielu artykułach i opracowaniach katalogowych są odnotowywane zwłaszcza wyroby pieczętarskie (zob. Zbiór tłoków i stempli pieczętnych w zasobie Archiwum Państwowego w Poznaniu, oprac. M. Górny, M. Hlebionek i in., pod red. P. Pokory, przy współpracy M. Hlebionka, Poznań 2015, nr kat. 24, 38, 49, 72, 363, 625, 722; E. Popiołek, Tłoki pieczętne w zbiorach płockich, Płock 1983, nr kat. 29; L. Formanowicz, dz. cyt., s. 490-494; J. Grabowski, Zbiory sfragistyczne Archiwum Głównego Akt Dawnych w Warszawie, [w:] Zbiory pieczęci w Polsce, pod red. Z. Piecha, W. Strzyżewskiego, Warszawa 2009, s. 77; E. Majkowski, Fryderyk Wilhelm Below: pieczętarz..., s. 301-323), ale także medalierskie, jubilerskie, złotnicze i in., zob. m.in.: E. Pokorzyńska, Początki polskiej oprawy wydawniczej: przegląd zabytków, „Acta Poligraphica” 2015, nr 6, s. 45 (plakiety); Przemyst, sztuka, polityka: wystawy gospodarcze na ziemiach polskich i z Polska zwiazanych ok. 1850-1914, red. W. Garbaczewski, Poznań 2015, nr kat. 35-36, 97 (medale); B. Dolczewska, Z. Dolczewski, Rzemiosło artystyczne w Wielkopolsce: piękne przedmioty i ozdoby, Poznań 2011, s. 170-171 (pierścień i brelok); Z. Dolczewski, Złotnictwo w XIX-wiecznym Poznaniu, KMP 2000, nr 1, s. 140 (sztylet z kości słoniowej).

${ }^{14}$ E. Majkowski, Fryderyk Wilhelm Below: pieczętarz..., s. 276-283.

${ }_{15}$ Tamże, s. 286. Zob. także nekrologi i krótkie wspomnienia pośmiertne w prasie: „Dziennik Poznański” z 21 lipca 1895, r. 37, nr 165, s. 6; „Dziennik Poznański” z 23 lipca 1895, r. 37, nr 166, s. 4; „Goniec Wielkopolski” z 21 lipca 1895, r. 19, nr 165, s. 3-4; „Goniec Wielkopolski” z 24 lipca 1895, r. 19, nr 167, s. 2; „Kurier Poznański” z 29 stycznia 1927, r. 22, nr 46, s. 9. 
1903), a przeniesiony w końcu życia założyciela zakład pieczętarski przy ul. św. Marcin prowadziła jego córka - Jadwiga Teresa (zm. 1927) ${ }^{16}$.

Na zakończenie należy raz jeszcze przypomnieć, że wytwórca stempla był wybitnym polskim artystą, wykonującym nie tylko pieczęcie, ale również medale, plakiety, rzeźby, wyroby złotnicze, jubilerskie i inne ${ }^{17}$. Publikowany stempel zaś, przy swoim niewielkim rozmiarze i małej wartości artystycznej, stanowi unikalny przykład prywatnego zamówienia. Przedstawiany artefakt uzupełnia listę znanych dotąd wyrobów pieczętarskich tego wytwórcy. Below doczekał się ponad to osobnej wystawy monograficznej wraz z sesją jemu poświęconą. Wystawa pt. Fryderyk Wilhelm Below (1822-1895) - pieczętarz $i$ artysta trwała od 1 września do 17 października 2015 r. w Muzeum Archidiecezjalnym w Poznaniu, a referaty w ramach sesji zostały wygłoszone w ostatnim dniu ekspozycji ${ }^{18}$.

Autor niniejszego tekstu chciał nawiązać i jednocześnie zachęcić do publikowania pojedynczych typariuszy pieczętnych, które dotychczas opracowywali historycy, archeolodzy, regionaliści i kolekcjonerzy ${ }^{19}$.

${ }^{16}$ E. Majkowski, Fryderyk Wilhelm Below: pieczętarz..., s. 286-290.

${ }^{17}$ Por. przypis 2.

${ }^{18}$ Sesja odbyła się w ramach III Uniwersyteckiego Seminarium Heraldycznego, które zorganizował Poznański Oddział Polskiego Towarzystwa Heraldycznego, zob. Sprawozdanie z dziatalności Poznańskiego Oddziału Polskiego Towarzystwa Heraldycznego przedstawione na setnym zebraniu naukowym, przygotowali do druku I. Kraszewski, M. Kadziszewska-Stróżyk, P. Stróżyk, Poznań 2019.

${ }^{19} \mathrm{~W}$ przeciągu ostatnich dwudziestu lat opublikowano następujące pozycje: D. Karczewski, Trzynastowieczny tłok pieczętny komesa Macieja Boguszyca, [w:] Heraldyka i okolice, red. A. Rachuba, S. Górzyński, H. Manikowska, Warszawa 2002, s. 193-199; D. Adamska, T. Stolarczyk, Stempel z tłoka rycerskiej pieczęci - znalezisko z okolic Jawora, "Studia Źródłoznawcze” 2004, t. 42, s. 79-84; A. Dębski, I. Marciniak, Tajemniczy brat Jakub - czternastowieczny lektor dominikański (przyczynek do studiów nad średniowieczna sfragistyka i monastycyzmem), „Folia Praehistorica Posnaniensia” 2004, t. 12, s. 251-264; tychże, Średniowieczny tłok pieczętny odkryty na stanowisku Poznań Ostrów Tumski 9/10, [w:] Poznań we wczesnym średniowieczu, t. 5, red. H. Kóčka-Krenz, Poznań 2005, s. 161-168; C. Chmielecki, Tłok pieczętny toruńskiej Gminy Żydowskiej z połowy XIX wieku, „Biuletyn Numizmatyczny” [dalej: Biul. Num.] 2006, nr 3, s. 221-222; tegoż, Tłok pieczętny Szkoty Rzemiost w Aleksandrowie Kujawskim, Biul. Num. 2010, nr 2, s. 137-140; tegoż, Tłok pieczęci stacji kolejowej Toruń-Miasto, Biul. Num. 2010, nr 4, s. 269-270; R. Forysiak-Wójciński, Ttok królewwskiej pieczęci Jana Olbrachta w Ossolineum, Arch. Pol. 2009, nr 3, s. 77-82; J.J. Dreścik, Typariusze pieczęci Szkoty Głównej Wielkiego Księstwa Litewskiego w Muzeum XX. Czartoryskich w Krakowie, [w:] "Żeby wiedzieć". Studia dedykowane Helenie Małkiewiczównie, Kraków 2008, s. 275-285; M.L. Wójcik, Czternastowieczny tłok pieczętny Piotra von Parchwitz, „Rocznik Polskiego Towarzystwa Heraldycznego" 2011, t. 10, s. 65-75; G.J. Brzustowicz, A. Kuczkowski, Gotycka pieczęć rycerska spod Choszczna, „Materiały Zachodniopomorskie” 2011, t. 8, z. 1: Archeologia, s. 241-250; A. Janowski, Średniowieczny tłok pieczętny (typariusz) z Wolina. Przyczynek do statusu społecznego szewców w małym mieście, „Kwartalnik Historii Kultury Materialnej” 2013, r. 61, nr 3, s. 453-462; A. Karpacz, Typariusz pieczętny z dawnego kościoła pw. św. Katarzyny Aleksandryjskiej w Krzeszowie a przestrzeń wiejskiej świątyni, „Zeszyty Naukowe Towarzystwa Doktorantów UJ. Nauki Społeczne" 2014, t. 9, z. 2, s. 183-209; J. Pierzak, Średniowieczny ttok pieczętny odkryty przy 


\section{Bibliografia}

\section{Źródła archiwalne}

Archiwum Państwowe w Poznaniu, Akta miasta Poznania - Kartoteka ewidencji ludności 18701931, sygn. 14270, k. 551-552.

\section{Prasa}

„Dziennik Poznański” 1895 (21 lipca), r. 37, nr 165, s. 6; 1895 (23 lipca), r. 37, nr 166, s. 4.

"Goniec Wielkopolski" 1895 (21 lipca), r. 19, nr 165, s. 3-4; 1895 (24 lipca), r. 19, nr 167, s. 2.

„Kurier Poznański” 1927 (29 stycznia), r. 22, nr 46, s. 9.

\section{Opracowania}

Adamska D., Dulęba P., Średniowieczny tłok pieczętny Lutolda von Hacke - znalezisko spod Bierzyna, pow. strzeliński, „Śląski Kwartalnik Historyczny Sobótka” 2015, t. 70, z. 3, s. 133-143.

Adamska D., Stolarczyk T., Stempel z tłoka rycerskiej pieczęci - znalezisko z okolic Jawora, "Studia Źródłoznawcze" 2004, t. 42, s. 79-84.

Brosig A., Dzieje sztuki litograficznej w Poznaniu, „Kronika Miasta Poznania” 1936, r. 14, nr 4, s. 405-447.

Brzustowicz G.J., Kuczkowski A., Gotycka pieczęć rycerska spod Choszczna, „Materiały Zachodniopomorskie" 2011, t. 8, z. 1: Archeologia, s. 241-250.

Chmielecki C., Tłok pieczętny toruńskiej Gminy Żydowskiej z połowy XIX wieku, „Biuletyn Numizmatyczny" 2006, nr 3, s. 221-222.

Chmielecki C., Ttok pieczętny Szkoty Rzemiost w Aleksandrowie Kujawskim, „Biuletyn Numizmatyczny" 2010, nr 2, s. 137-140.

Chmielecki C., Tłok pieczęci stacji kolejowej Toruń-Miasto, „Biuletyn Numizmatyczny” 2010, nr 4, s. 269-270.

Derwojed J., Below Fryderyk Wilhelm, [w:] Stownik artystów polskich i obcych w Polsce działających: malarze, rzeźbiarze, graficy, red. J. Maurin-Białostocka, M. Biernacka i in., WrocławWarszawa-Kraków-Gdański 1971, t. 1, s. 124-125.

Dębski A., Marciniak I., Średniowieczny tłok pieczętny odkryty na stanowisku Poznań - Ostrów Tumski 9/10, [w:] Poznań we wczesnym średniowieczu, red. H. Kóčka-Krenz, Poznań 2005, t. 5, s. $161-168$.

Dębski A., Marciniak I., Tajemniczy brat Jakub - czternastowieczny lektor dominikański (przyczynek do studiów nad średniowieczna sfragistyka i monastycyzmem), „Folia Praehistorica Posnaniensia” 2004, t. 12 , s. 251-264.

Dolczewska B., Dolczewski Z., Rzemiosło artystyczne w Wielkopolsce: piękne przedmioty i ozdoby, Poznań 2011.

kościele pod wezwaniem św. Jakuba Apostoła w Gieble, woj. ślaskie, [w:] Wiadomości konserwatorskie województwa ślaskiego, t. 6: Dom - zabytkowa architektura mieszkalna, red. A. Borowik, Katowice 2014, s. 203-216; M. Hlebionek, Piętnastowiecznych rycerski ttok pieczętny ze zbiorów Muzeum Poczatków Państwa Polskiego w Gnieźnie, "Studia nad Dawną Polską" 2015, t. 4, s. 111-120; D. Adamska, P. Dulęba, Średniowieczny tłok pieczętny Lutolda von Hacke - znalezisko spod Bierzyna, pow. strzeliński, „Śląski Kwartalnik Historyczny Sobótka” 2015, t. 70, z. 3, s. 133-143; K.M. Kowalski, Typariusz Stefana z Jani jako wyjątkowe świadectwo polskiej sfragistyki rycerskiej na Pomorzu Gdańskim, [w:] Stilo et animo. Prace historyczne ofiarowane Profesorowi Tomaszowi Jasińskiemu w 65. rocznicę urodzin, red. M. Dorna, M. Matla, M. Sosnowski, E. Syska, przy współpracy W. Barana-Kozłowskiego, Poznań 2016, s. 507-515. 
Dolczewski Z., Złotnictwo w XIX-wiecznym Poznaniu, „Kronika Miasta Poznania” 2000, nr 1, s. 131-142.

Dolczewski Z. (oprac.), Spis złotników poznańskich w XIX wieku - do pocz. XX w., „Kronika Miasta Poznania" 2000, nr 1, s. 143-152.

Dreścik J.J., Typariusze pieczęci Szkoły Głównej Wielkiego Księstwa Litewskiego w Muzeum XX. Czartoryskich w Krakowie, [w:] "Żeby wiedzieć". Studia dedykowane Helenie Małkiewiczównie, Kraków 2008, s. 275-285.

Fabijański W., Próba klasyfikacji i nazewnictwa pieczęci używanych w kancelariach urzędów oraz instytucji polskich XX wieku, [w:] Dawne pieczęcie: typologia - metody badan - interpretacje, pod red. Z. Piecha, Warszawa 2015, s. 553-579.

Formanowicz L., Przyczynek do działalności rytowniczej Fryderyka Wilhelma Belowa, „Kronika Miasta Poznania" 1936, r. 14, nr 3, s. 490-494.

Forysiak-Wójciński R., Tłok królewskiej pieczęci Jana Olbrachta w Ossolineum, "Archiwista Polski” 2009, nr 3, s. 77-82.

Gibasiewicz S., Medalierzy poznańscy XIX wieku, [w:] Materiały z I Ogólnopolskiej Sesji Medalierskiej, red. J. Hrybacz, Z. Nowakowska, T. Szczurek, Gorzów Wielkopolski 1974, s. 29-32.

Grabowski J., Zbiory sfragistyczne Archiwum Głównego Akt Dawnych w Warszawie, [w:] Zbiory pieczęci w Polsce, pod red. Z. Piecha, W. Strzyżewskiego, Warszawa 2009, s. 31-78.

Gradowski M., Dawne złotnictwo: technika i terminologia, Warszawa 1984.

Grot Z., F. W. Below: wybitny medalier wielkopolski i patriota, "Złotnik i Zegarmistrz" 1936, nr 8, s. 154-155.

Gumowski M., Medale polskie, Warszawa 1925.

Gut P., Problemy inwentaryzacji kolekcji tłoków pieczętnych w Archiwum Państwowym w Szczecinie, „Archiwista Polski" 2007, nr 1, s. 7-13.

Hlebionek M., Piętnastowiecznych rycerski tłok pieczętny ze zbiorów Muzeum Początków Państwa Polskiego w Gnieźnie, „Studia nad Dawną Polską" 2015, t. 4, s. 111-120.

Janowski A., Średniowieczny tłok pieczętny (typariusz) z Wolina. Przyczynek do statusu społecznego szewców w matym mieście, „Kwartalnik Historii Kultury Materialnej” 2013, r. 61, nr 3, s. 453462.

Karczewski D., Trzynastowieczny tłok pieczętny komesa Macieja Boguszyca, [w:] Heraldyka i okolice. Księga pamiątkowa ofiarowana profesorowi Stefanowi Krzysztofowi Kuczyńskiemu, red. A. Rachuba, S. Górzyński, H. Manikowska, Warszawa 2002, s. 193-199.

Karpacz A., Typariusz pieczętny z dawnego kościoła pw. św. Katarzyny Aleksandryjskiej w Krzeszowie a przestrzeń wiejskiej świątyni, „Zeszyty Naukowe Towarzystwa Doktorantów Uniwersytetu Jagiellońskiego. Nauki Społeczne" 2014, t. 9, z. 2, s. 183-209.

Kłudkiewicz K., Księgozbiór kolekcjonera dzieł sztuki. Słów kilka o bibliotece Seweryna hr. Mielżyńskiego z Miłostawia, „Biblioteka” 2015, nr 19, s. 81-116.

Kowalski K.M., Typariusz Stefana z Jani jako wyjątkowe świadectwo polskiej sfragistyki rycerskiej na Pomorzu Gdańskim, [w:] Stilo et animo. Prace historyczne ofiarowane Profesorowi Tomaszowi Jasińskiemu w 65. rocznice urodzin, red. M. Dorna, M. Matla, M. Sosnowski, E. Syska, przy współpracy W. Barana-Kozłowskiego, Poznań 2016, s. 507-515.

Majkowski E., Fryderyk Wilhelm Below, [w:] Polski stownik biograficzny, t. I, s. 407-408.

Majkowski E., Fryderyk Wilhelm Below: pieczętarz i medaljer poznański, patriota polski (1822-1895), „Kronika Miasta Poznania” 1936, r. 14, nr 3, s. 263-349.

Majkowski E., Nieznana praca medalierska Fryderyka Wilhelma Belowa, rytownika i pieczętarza poznańskiego, „Kronika Stołecznego Miasta Poznania” 1946, r. 19, nr 1, s. 58-62.

Michałowski P., Below Fryderyk Wilhelm (1822-1895), [w:] Wielkopolski słownik biograficzny, Warszawa-Poznań 1981, s. 46.

Pamiątki przeszłości 1796-1945: berlińska linia Radziwiłtów. Muzeum w Nieborowie i Arkadii i Fundacja Trzy Trąby, 16 czerwca - 31 października 2018, Nieborów 2018. 
Pierzak J., Średniowieczny tłok pieczętny odkryty przy kościele pod wezwaniem św. Jakuba Apostoła w Gieble, woj. ślaskie, [w:] Wiadomości konserwatorskie województwa śląskiego, t. 6: Dom - zabytkowa architektura mieszkalna, red. A. Borowik, Katowice 2014, s. 203-216.

Pokorzyńska E., Początki polskiej oprawy wydawniczej: przegląd zabytków, „Acta Poligraphica" 2015, nr 6, s. 37-50.

Popiołek E., Tłoki pieczętne w zbiorach płockich, Płock 1983.

Przemyst, sztuka, polityka: wystawy gospodarcze na ziemiach polskich i z Polska zwiazanych ok. 18501914, red. W. Garbaczewski, Poznań 2015.

Solecki A., Ks. Edmund Majkowski, Fryderyk Wilhelm Below, pieczętarz i medalier poznański, patriota polski, 1822-1895. Poznań 1936, „Wiadomości Numizmatyczno-Archeologiczne” 1936, t. 28, s. 138-139.

Sprawozdanie z działalności Poznańskiego Oddziatu Polskiego Towarzystwa Heraldycznego przedstawione na setnym zebraniu naukowym, przygotowali I. Kraszewski, M. Kadziszewska-Stróżyk, P. Stróżyk, Poznań 2019.

Strzałkowski J., Stownik medalierów polskich i z Polską związanych 1508-1965 (materiały), Warszawa 1982.

Stróżyk P., Pieczęćnaczelnika miasta Poznania z okresu powstania styczniowego. Zagadnienia autorstwa, [w:] Pomerania et alia. Opuscula Joachimo Zdrenka dedicata, red. J. Karczewska, M. Tureczek, Toruń 2017, s. 275-280.

Sukiennik G., Katalog tłoków pieczętnych w zbiorach Biblioteki Ossolineum. Nabytki z lat 1978-1984, „Ze Skarbca Kultury" 1987, z. 44, s. 249-256.

Sztakelberg J.I., Pieczęcie powstańcze 1863-1864, przedmowa S. Kieniewicz, tabl. i il. do druku przygotował S.K. Kuczyński, przekł. W. Śliwowska, Warszawa 1988.

Trupinda J., Tłoki pieczętne w zbiorach Muzeum Narodowego w Gdańsku, „Rocznik Gdański” 2000, t. 60, z. 2, s. 99-109.

Więcek A., Dzieje sztuki medalierskiej w Polsce, Kraków 1989.

Wójcik M.L., Czternastowieczny tłok pieczętny Piotra von Parchwitz, „Rocznik Polskiego Towarzystwa Heraldycznego" 2011, t. 10, s. 65-75.

Zbiór tłoków i stempli pieczętnych w zasobie Archiwum Państwowego w Poznaniu, oprac. M. Górny, M. Hlebionek, J. Jarębska, I. Jaskólska, D. Jasiński, P. Kaleta, K. Okoniewska, J. Wysocki, P. Pokora, S. Tomczak, W. Siudek, pod red. P. Pokory, przy współpracy M. Hlebionka, tłum. E. Jiya, D. Młodzianowska-Pilczuk, Poznań-Warszawa 2015.

\section{Szymon Bauman}

\section{Nieznany wyrób pieczętarski Fryderyka Wilhelma Belowa (Komunikat)}

\section{Streszczenie}

Publikacja niniejsza prezentuje nieznany stempel pieczętny, który wykonał Fryderyk Wilhelm Below - znakomity poznański artysta, medalier i pieczętarz. W komunikacie zamieszczono opis pieczęci zawierający podstawowe informacje o jej kształcie, materiale, wymiarach i napisie napieczętnym. Obiekt ten, przy swoim niewielkim rozmiarze, stanowi unikalny przykład prywatnego zamówienia. Przedstawiany artefakt uzupełnia listę znanych dotąd wyrobów pieczętarskich tego wytwórcy.

Słowa kluczowe: Poznań, Fryderyk Wilhelm Below, pieczętarz, grawer, pieczęć, typariusz pieczętny 
Szymon Bauman

\title{
Unknown seal matrix by Fryderyk Wilhelm Below. (Announcement)
}

\begin{abstract}
This publication presents an unknown seal matrix, made by Fryderyk Wilhelm Below - a remarkable Poznań artist, medalist, and seal maker. The announcement provides a description of the seal including basic information about its shape, material, dimensions, and inscription. This object, with its small size, is a unique example of a private order. The presented artefact supplements the list of known products made by this seal maker.
\end{abstract}

Keywords: Poznań, Fryderyk Wilhelm Below, seal maker, engraver, seal, seal matrix 